DE

\title{
Conceptual metaphors in Ukrainian prime ministers' discourse involving renewables
}

\author{
Oleksandr Kapranov \\ University of Bergen, Norway
}

\begin{abstract}
This qualitative study is aimed at elucidating conceptual metaphors associated with renewable energy sources (further referred to as 'renewables') in Ukrainian prime ministers' (PMs) political discourse. The material derives from a corpus of Ukrainian PMs' political texts on renewables in Ukraine within the timeframe 2005-2014. The corpus is examined for the presence of conceptual metaphors pertaining to the topic of renewables. Data analysis indicates that from 2005 to 2013 conceptual metaphors involving renewables are embedded in the issues of Ukraine's adherence to the Kyoto Protocol, the EU directives on renewables, the monetary value of renewables and the role of renewables in Ukraine's energy security, thus instantiating the conceptual metaphors Renewables as Ukraine's European Choice, Renewables as a Path to the EU, Renewables as Money and Renewables as Independence respectively. However, the novel metaphor Renewables as Survival is identified in PM Yatsenjuk's political discourse in 2014. This metaphor is embedded in the context of another conceptual metaphor, Gas as a Weapon, which is present in political discourse involving Russian natural gas export to third countries. Data analysis indicates that the conceptual metaphors Renewables as Survival and Renewables as Independence are in a polyphonic relationship of synergy and contrast with Gas as a Weapon.
\end{abstract}

\section{Keywords}

cognitive linguistics, conceptual metaphor, construal, political discourse, renewables.

\section{Introduction}

Renewables are reflected in political discourse as a facet of the issue of global climate change (Becken, 2014; Fløttum, et al., 2014) and national energy security (Trombetta, 2008) respectively. The literature indicates that renewables are characterized by an important role in the political agenda of the major industrial nations in combatting the negative consequences of global climate change (Chum and Overend, 2001; Fløttum, et al., 2014). Recent research has emphasized the role of renewables in global geopolitics and in the domestic politics of a number of Eastern European countries, e.g. Poland and Ukraine, where renewables are considered a significant variable in decreasing these countries' energy dependence on natural gas and oil imports from Russia (Jaspal, et al., 2014).
This article examines political discourse by Ukrainian PMs within the timeframe 2005 2014, seeking to identify conceptual metaphors involving renewables. Further in this article, there will be provided: i) a theoretical background of conceptual metaphor in political discourse referring to traditional and renewable energy sources; ii) an outline of the political background in reference to renewables in Ukraine within the timeframe $2005-2014$ and iii) a cognitive linguistic analysis of conceptual metaphors pertaining to renewables in political discourse by Ukrainian PMs from 2005 to 2014.

The novelty of the present research rests with the following considerations: first, no previous studies have been conducted on the discoursal space of Ukrainian PMs involving renewables. Second, a novel facet of this qualitative investigation is its 
methodological grounding in the apparatus of cognitive linguistics with a specific focus on conceptual metaphor.

1. Theoretical background: conceptual metaphor in political discourse involving renewables and traditional energy sources Political discourse involves a polyphony of situations, events, actors, groups and political beliefs (Fløttum, et al., 2014; van Dijk, 2002; Wilson, 2000; Wodak, 2011). Political discourse simultaneously represents, signifies and construes social reality (De Cillia, et al., 1999; Chilton, 2004; Hart, 2008). The cognitive linguistic paradigm posits that the construction of a particular communicative space in political discourse is facilitated by metaphoric language (Musolff, 2006). Its production and comprehension are mediated by metaphorical correspondences that structure mental representations of complex concepts (McGlone, 2007, p.111).

It is assumed that political discourse is structured by a variety of conceptual metaphors that contribute to the creation of socio-political identities, ideological systems and mental spaces (Chilton, 2004; Nerlich, 2010; Paasi, 2001). Metaphors in political discourse are regarded "as cues to social identity by virtue of their capacity to shape what else people think about when they read or hear about politics" (Anderson, 2001, p. 313). Metaphors as a part of political discourse possess a distinctive social relevance (Gibbs, 2011). Presumably, sociocognitively relevant metaphors enrich social cognition (IJserman and Koole, 2011) by foregrounding and conveying novel or abstract ideas in a familiar and mostly concrete manner (Lakoff and Johnson, 1980). Thus, metaphors constitute one of the salient framing devices (Nerlich, 2010) in instantiating political scenarios by means of combining conceptual elements from different and distinct domains of experience into mini narratives (Musolff, 2004). An illustration of a narrative structure that involves cross-domain mappings is provided by the extensively researched conceptual metaphor EU (the European Union) as a House, where concrete and easy-tounderstand conceptual features of House are mapped onto the abstract domain of a political entity, namely the EU (Musolff, 2006). In the present article, conceptual metaphor is analysed in a similar manner, as mappings between two distinct and unrelated domains of experience (Lakoff and Johnson, 1980).

Discursive realities constructed with the help of conceptual metaphors are extensively employed in political discourse involving the issue of global climate change (Carvalho, 2010; Rogers-Hayden, et al., 2011; Nerlich, 2010; Shaw and Nerlich, 2015), renewables (Boudet, et al., 2014; Princen, 2010) and traditional energy sources (Bilgin, 2011; Lancor, 2014; Smith Stegen, 2011). In particular, traditional energy sources such as natural gas, exported by Russia to EU and non-EU Eastern European countries, have been metaphorically construed as a "gas card" used by the Russian state and Russian energy companies (Bilgin, 2011, p. 120). To elucidate this construal, let us reiterate the view of conceptual metaphor as a mapping between two distinct domains of experience (Lakoff and Johnson, 1980). Assuming that the domains Gas and Card Game are distinct and not directly related, it follows that there are possible mappings between these two domains. For instance, conceptual elements from Gas are mapped onto Card Game, whereby concepts associated with a card game are mapped onto mental representations of a card player, who uses natural gas as an ace card to win the Card Game. Thus, the mapping between Gas and Card Game gives rise to the conceptual metaphor Gas as a Card Game. This conceptual metaphor is illustrated by Nygren (2008, p. 3) who posits that "Putin plays the energy card as exports of natural gas by state-controlled exporters to gas-dependent CIS consumer countries as foreign policy instruments." It should be noted that Gas as a Card Game is a deliberate metaphor, since its cross-domain mappings involve a relatively conscious discourse strategy (Steen, 2008).

Presumably, a plethora of cross-mappings exists between the domain Gas and other unrelated domains of experience. For instance, a mapping of conceptual elements from Gas onto Weapon instantiates the conceptual metaphor Gas as a Weapon. This metaphor refers to natural gas, which the Russian Federation employs as a weapon in achieving its political objectives (Rutland, 2008; Smith, 2006). Research indicates that from the 1990s onwards Russia has increasingly started to regard its gas as a means of pressuring importer countries (Lilliestam and Ellenbeck, 2011). Current Russian economic identity is characterized by fuzzy boundaries between economic and 
ideological practices where gas exports are associated with Russia's geopolitics and its national identity as a superpower (Katz, 2005; Tarus and Crandall, 2012). Interestingly, even at the height of the Cold War, discourse referring to the so-called "red" gas exported from the old Soviet Union seems to be embedded in a de-ideologized or politically neutral discoursal space (Bilgrin, 2011; Högselius, 2013). However, in the present economic climate it can be claimed that the blend of economy and ideology in Russia's gas export stipulates a highly emotive and metaphoric political discoursal context marked by the conceptual metaphor Gas as a Weapon.

The conceptual metaphor Gas as a Weapon is amply illustrated in the research literature (Smith, 2006). For instance, Cameron (2010, p.23) posits that "Putin has always been ready to use energy as a political weapon abroad". It is observed that the state-owned gas corporation Gasprom is "a political weapon... which uses gas supply as a coercive or punitive tool" (Smith Stegen, 2011 , p. 6506). Gas and the gas pipeline is "a political tool for Russia in its relationship with Ukraine" (Wigen, 2012, p. 599). The practice of halting gas supplies is concurrent with the Russian Federation's endeavours to launch alternative gas pipeline projects "in order to exert pressure on Belorussia and Ukraine" (Malek, 2012, p. 6). It has been established in previous studies that the metaphor Gas as a Weapon is present in discourse involving politically motivated disruptions of the gas supply from Russia to European consumers, described as the energy wars between Russia and Ukraine (Blank, 2008; Goldman, 2010; Nichol, et al., 2006; Smith, 2007; Smith Stegen, 2011). Referring to the Russo-Ukrainian energy wars, Bilgin (2011, pp.122-123) argues that in 2006 and 2009 "the Kremlin was ready to use gas as a political tool as it did against Ukraine's Orange Revolution".

Consequently, current political discourse in several Eastern European countries, especially in Poland and Ukraine, foregrounds the role of renewables such as biofuel, wind and solar energy to increase these countries' energy security (Jaspal, et al., 2014). It can be argued that renewables are regarded in Eastern European political discourse as a construal which is in contrast with Gas as a Weapon. Presumably, the metaphors in opposition to Gas as a Weapon are instantiated by several cross-domain mappings, such as from Renewables onto
Survival and from Renewables onto Independence respectively, thus resulting in metaphors Renewables as Survival and Renewables as Independence. These conceptual metaphors are embedded in the discoursal space where the country's identity, security and sovereignty critically depend on energy sources other than Russian-supplied gas (Jaspal, et al., 2014).

Whilst there are multiple studies involving the conceptual metaphor Gas as a Weapon (Bilgrin, 2011; Högselius, 2013; Lilliestam and Ellenbeck, 2011; Nichol, et al., 2006; Smith Stegen, 2011; Walker, 2007), Renewables as Survival and Renewables as Independence respectively have hardly been elucidated. Currently, there are a few research articles which consider renewables as a variable in maintaining a country's independence, economic progress and national sovereignty (Boudet, et al., 2014). These studies indicate that renewables in Eastern Europe, specifically in Poland, are regarded as a means of ensuring independence from Russian gas (Jaspal, et al., 2014). Given the geo-political closeness of Poland and Ukraine in terms of these two countries' energy supplies and energy policies, Ukrainian political discourse would also involve construals of renewables similar to Renewables as Independence.

\subsection{Political background: the Ukrainian government's stance on renewables from 2005 to 2014}

The scope of the present study encompasses Ukrainian PMs' political discourse on renewables from 2005 to 2014. After the formation of the first Tymoshenko government in 2005, the issue of renewables is regarded in conjunction with the Kyoto Protocol. Tymoshenko's active involvement in the Kyoto Protocol to combat global climate change and to introduce renewables under the aegis of the Protocol can be attributed to the ecologically conscious public opinion (Shkarlet and Petrakov, 2013). Interestingly, the theme of renewables as a means of ensuring Ukraine's independence from Russian gas is not present in Tymoshenko's discourse during the 2006 energy war with the Russian Federation.

In 2005-2006, PM Yehanourov's discourse involving renewables is embedded into the discoursal space of Ukraine's EU aspirations. Yehanurov regards renewables as one of the necessary steps in bringing Ukraine closer to the EU (Ralbovsky, 2011). However, concurrently with the emphasis on the wider 
application of renewables to conform to EU regulations, Yehanourov's government launches a programme of revitalizing Ukraine's nuclear energy sector.

PM Yanoukovych's political discourse involving renewables is focused on the Kyoto Protocol mechanisms to be adhered to and implemented by Ukraine (Katz, 2005, pp. 2536; Smith, 2007). Additionally, Yanoukovych's government plans to initiate a wind energy park in Southern Ukraine to facilitate Ukraine's curtailment of its carbon gas emission within the framework of the Kyoto Protocol (Zherybor, 2010) and to attract international investment, predominantly from the EU.

PM Tymoshenko's government discourse on renewables during 2007-2010 involves the Kyoto Protocol as a means of combatting global climate change (Kratochvíl, et al., 2011; Obydenkova and Libman, 2014). Additionally, Tymoshenko's political discourse on renewables is marked by the yet-to-be signed EU-Ukraine Association Agreement (AA). The EU-Ukraine AA envisages institutionalized provisions for ecological standards, renewables and energy policies common with the EU. Hence, adherence and implementation of the Kyoto Protocol by Ukraine is regarded as a part of the EU-Ukraine AA.

Azarov's (2010-27.01.2014) government views renewables within the context of the EU-Ukraine AA (Blockmans and Van Vooren, 2012). Additionally, renewables are regarded as a means of attracting investment from abroad by promulgating Ukraine as a potential energy hub. Azarov's discourse on renewables foregrounds the importance of biofuel and solar energy as a means of counterbalancing Ukraine's reliance on natural gas imported from Russian under the 2009 gas contract signed by Tymoshenko (Azarov, 2010).

PM Yatsenjuk's (2014 - current) discourse involving renewables seems to be embedded in a context which differs significantly from the discursive space of his predecessors. Specifically, during the cadencies of Azarov, Tymoshenko, Yehanourov and Yanoukovych Ukraine had never been directly involved in an armed conflict on its own territory. In contrast with that of his predecessors, PM Yatsenjuk's time in office is marked by the annexation of Crimea in March 2014 and the war in Eastern Ukraine. Given that Ukraine is critically dependent on Russian gas, Yatsenjuk continuously refers to Russian gas as a new political weapon to pressure
Ukraine in the heretofore unknown realities of war. Furthermore, Yatsenjuk compares Russian gas with a nuclear weapon which threatens both Ukraine and the EU. It should be reiterated that PM Yantsenjuk's discourse is situated in novel political conditions, which Ukraine's political landscape had not been exposed to prior to 2014 .

\section{Hypothesis and specific research questions}

Following previous research (Romaine, 1996), it was hypothesized that political discourse by Ukrainian PMs involving renewables would be marked by a number of conceptual metaphors. Based upon the current literature (Cameron, et al., 2009; Nerlich, 2010), it was theorized that the tobe-identified conceptual metaphors would be dynamically adjusted to the discourse situation, hence varying over time. Assuming that the metaphoric space was dynamic and critically dependent on the particular political situation, it was hypothesized that PM Yatsenjuk's discourse on renewables would be characterized by conceptual metaphors qualitatively different from the to-be-identified metaphors in discourse on renewables by Yatsenjuk's predecessors. That assumption took into consideration the war in the East of Ukraine and strained political relations between Ukraine and Russia during Yatsenjuk's time in office as a PM. In concert with previous research findings (Blank, 2008; Högsenius, 2013), it was assumed that the presence of the conceptual metaphor Gas as a Weapon in the political discourse involving gas supplies to European consumers by Russia would characterize the discoursal space of Ukrainian PMs. Arguably, the instantiation of specific conceptual metaphors in Ukrainian PMs' discourse would be in contrast with the aforementioned conceptual metaphor.

Thus, the following specific research aims were formulated: i) to identify conceptual metaphors in Ukrainian PMs' political discourse involving renewables; ii) to elucidate whether or not conceptual metaphors pertaining to the issues of renewables in PMs' political discourse would be embedded into the presence of the conceptual metaphor Gas as a Weapon; iii) to investigate whether or not the conceptual metaphor Gas as a Weapon would be instantiated in Ukrainian PMs' political discourse as Renewables as a Weapon. 


\section{Methodology}

The qualitative methodology used in the present research involved conceptual metaphor identification formulated by Lakoff and Johnson (1980) and Gibbs (2011) respectively, who posited that conceptual metaphor involved mappings between two distinct and unrelated domains of experience. Informed by the aforementioned view of conceptual metaphor as a cross-domain mapping, the methodology involved identification of the source and target domains in the corpus of Ukrainian PMs texts on renewables. The following key words were used: alternative energy sources, biofuel, biogas, biomass, green fuel, renewable energy, solar energy, and wind energy respectively. Whilst key words shale gas and fracking were subsumed under alternative energy sources in political texts by several Ukrainian PMs, shale gas and fracking were excluded from the analysis. The corpus in the present study was analysed in accordance with the qualitative methodology of conceptual metaphors analysis described by Nerlich (2010). Following Nerlich (2010), domain identification involved key-words extraction in the corpus, with domains being identified in the whole discourse chunk which contained the key words. Then, it was examined whether or not there were mappings of conceptual elements in unrelated domains.

\section{Materials}

The materials of the present study were garnered from the official web pages of the Ukrainian government, publicly available at the website of the Cabinet of Ministers of Ukraine www.kmu.gov.ua, the Ukrainian government official website zakon4.rada.gov.ua, the government-owned newspaper Urjadovyj Kurjer www.ukurier.gov.ua, the government-run news agency Ukrinform www.ukrinform.ua and other websites (see Appendix 1). The corpus was compiled by an electronic search of the PMs' texts referring to the issues of renewables from the period of January 2005 until December 2014. In total, 34 documents were analysed. The original corpus was in the Ukrainian language, with one text by PM Azarov in Russian. The illustrative examples provided in the present article were translated from Ukrainian and from Russian into English by the author. The corpus comprised six texts by PM Tymoshenko (Mean number of words 2016 ), two texts by PM Yehanourov (M words 241), three texts by PM Yanoukovych (M words 164), 13 texts by PM Azarov (M words 758) and 10 texts by PM Yatsenjuk (M words 438). The overall genre of the corpus was political discourse presented by the PMs themselves. The inclusion criteria for the corpus compilation involved the following variables: first, to ensure genre consistency, only texts published electronically by the Ukrainian government were considered. Second, to make the corpus comparable and genre coherent, only political texts officially authored by the PMs were taken into consideration.

\section{Results and discussion \\ Qualitative analysis has yielded several conceptual metaphors pertaining to renewables in the corpus of Ukrainian PMs' texts from 2005 till 2104. The results are summarized in Table 1 below.}

Table 1. Conceptual metaphors in Ukrainian PMs' texts involving renewables

\begin{tabular}{|c|c|c|}
\hline PM & Time in office & Conceptual metaphor \\
\hline Tymoshenko & $2005,2007-2010$ & $\begin{array}{l}\text { Renewables as Money } \\
\text { Renewables as Independence }\end{array}$ \\
\hline Yehanurov & $2005-2006$ & $\begin{array}{l}\text { Renewables as Ukraine's European Choice } \\
\text { Renewables as Independence }\end{array}$ \\
\hline Yanukovych & $2006-2007$ & Renewables as Money \\
\hline Azarov & $2010-2014$ & $\begin{array}{l}\text { Renewables as Independence } \\
\text { Renewables as Money } \\
\text { Renewables as Ukraine's European Choice } \\
\text { Renewables as a Path to the EU }\end{array}$ \\
\hline Yatsenjuk & 2014 & $\begin{array}{l}\text { Renewables as Independence } \\
\text { Renewables as Survival }\end{array}$ \\
\hline
\end{tabular}

Descriptive statistics are presented in Table 2 below. These statistics involve the number of occurrences of conceptual metaphors in the corpus. 
Table 2. Number of occurrences of conceptual metaphors in the corpus

Conceptual metaphor Total N Total N per PM

\begin{tabular}{|c|c|c|}
\hline Renewables as Money & 19 & Tymoshenko 3, Yanoukovych 4, Azarov7 \\
\hline Renewables as Independence & 15 & $\begin{array}{l}\text { Tymoshenko 3, Yehanourov 2, Azarov 4, } \\
\text { Yatsenjuk } 6\end{array}$ \\
\hline Renewables as Survival & 5 & Yatsenjuk 5 \\
\hline Renewables as Ukraine's & 2 & Yehanourov 1, Azarov 1 \\
\hline
\end{tabular}

EU Choice

Renewables as a Path to the EU 1 Azarov 1

As evident from Table 1, the framing of Renewables in political discourse by Ukrainian PMs involves several metaphoric construals. Data analysis indicates that Ukrainian PMs' discourse on Renewables is associated with construing them as crossdomain mappings onto Money, Independence, Ukraine's European Choice, Path to the EU and Survival respectively. Regarded within the broader context of cognitive linguistics debate, the present data highlight the significance of the notion of construal, a topical issue in the current cognitive paradigm (Hart, 2008). Following Langacker (1991), construals in general involve multiple conceptualizations of identical phenomena. Furthermore, these conceputalizations are reliant on alternative language structures imposed on the particular scene or discursive frame. In this regard, Hart (2014) posits that linguistic structures reflect the text-producers' specific points of view in construing an ideological discursive space. The current literature in cognitive linguistics suggests that the structuring of ideological discursive spaces is enabled by metaphoric construals, alongside force-dynamics and other elements of conceptualization (Croft and Cruse, 2004; Hart, 2008). Construals involving cross-domain mappings, i.e. conceptual metaphor, serve to realize such discursive strategies as identification, framing and positioning (Hart, 2011, p.271). Taking this line of argument into consideration, the results of the present investigation can be seen as embedded into a view of cross-domain construals which facilitate both the framing and positioning of Renewables in political discourse by Ukrainian PMs.

Viewed from a general perspective, the present findings are reflective of recent debates in social psychology, political sciences and cultural discourse which indicate that both political and public opinions involving Renewables are multifaceted (Pidgeon, 2012). Specifically, the results summarized in Table 2 indicate the influence of political dynamics on the PMs' attitudes to renewables, which seem to be associated with the concept Money in a stable socio-political environment. However, Renewables tend to exhibit stronger ties with the concept Survival in the context of the ongoing war in the East of Ukraine. Following Pidgeon et al. (2003), it should be noted that the present findings provide an example of how the changing social context amplifies and attenuates public discourse in general and political discourse in particular (Pidgeon, 2012).

The results of the data analysis reveal that Ukrainian PMs' discourse on renewables involves the following conceptual metaphors: Renewables as Money, Renewables as Independence, Renewables as Ukraine's European Choice, Renewables as a Path to the EU and Renewables as Survival respectively. It should be reiterated that these metaphors are interconnected with the dynamics of Ukrainian political reality. This reality is exacerbated by Ukraine's critical reliance on natural gas, predominantly imported from Russia. Hence, renewables are regarded by the governments of Tymoshenko, Yehanurov, Azarov and Yatsenjuk respectively as a means of securing Ukraine's energy independence. Data analysis reveals that Renewables as Independence represents a consistent metaphoric space in Ukrainian PMs' discourse, with PM Yanukovych being a notable exception. The construal of renewables as having monetary value is expressed by the metaphor Renewables as Money, identified in political discourse by Tymoshenko, Yanukovych and Azarov. Since Ukraine's political reality is significantly influenced by its pro-EU aspirations, renewables are regarded as a facet of European identity. Consequently, the identification of renewables with the EU is instantiated by metaphors Renewables as Ukraine's European Choice and Renewables as Ukraine's European Choice found in PMs 
Yehanurov and Azarov's discourse. Data suggest that renewables are conceptualized as a matter of Ukraine's survival in the context of Russian politics of using natural gas as a political weapon. This gives rise to the metaphor Renewables as Survival, which is present exclusively in PM Yatsenjuk's political discourse. These findings may have the following implications relevant to energy policy in Ukraine in particular and in postcommunist Eastern Europe in general: first, renewables are critically important in reducing the country's strategic import of traditional energy supplies, such as natural gas. Second, renewables are subject to a substantial monetary value in the absence of military conflicts. Third, renewables are associated with energy efficiency and ecological standards applied by the EU to potential candidate-countries. Fourth, the monetary, ecological and EU-related values of renewables appear to be irrelevant in the context of military conflict.

\subsection{Renewables as money}

Data analysis indicates that cross-domain mappings between Renewables and Money lead to the metaphor Renewables as Money. This metaphor is identified in political discourse involving renewables by PMs Tymoshenko, Yanukovych and Azarov. The monetary value of renewables is consistently present in Tymoshenko's discourse, as evident from excerpts (1) and (2) below:

(1) We will facilitate the development of alternative and renewable energy sources. From 1 January 2010 those enterprises which produce energy from renewable sources - water, wind, sun, wood, biofuel have been granted tax breaks.

(2) We opened a new system of financing the country. This involves Ukraine's participation in the Kyoto Protocol, when the country by means of reducing its carbon emissions into the atmosphere can receive money to help finance the emission reduction. The Kyoto Protocol is very simple: cut carbon emissions, get the economy better, get the money for it into the budget.

Interestingly, in (2) Tymoshenko embeds the issue of renewables and their monetary value into the context of the Kyoto Protocol. This finding is in concert with previous research, which posits that Ukraine's budget revenues from the Kyoto Protocol gas emission trading scheme "...have been keenly and successfully developed as a vehicle to modernize the economy. Ukraine has emphasized the achievement of its
Kyoto commitments and has aimed to ensure room for economic growth" (Korppoo and Gassan-Zade, 2014, p. 229). Similarly to Tymoshenko, Azarov views renewables as a means of attracting money into the country in the forms of 'green investments'. For instance, in negotiations with Japanese business investors in 2011 Azarov refers to Renewables as Money in (3):

(3) The development of alternative energy sources is very important for Ukraine, especially in connection with the high price for imported gas... for Ukraine it is also important to attract capital in the framework of 'green' investments. In this regard, the Government is ready to provide guarantees that these investments will not be embezzled. I can very clearly guarantee that all the money which we are getting will be directed exclusively towards the realization of ecological projects.

In addition to the 'green' investments in renewables, Azarov frames Renewables as Money within the context of the high gas prices which Ukraine pays for natural gas imported from Russia, as evident from excerpt (4) below:

(4) We continue negotiations with the Russian Federation about exorbitant gas prices, but in this regard the focus will be on our own resources to ensure that we use alternative energy sources instead of gas, to extract more coal, to minimize energyintensive communal services.

It should be reiterated that Renewables as Money is present in discourse by those PMs associated with big business, i.e. the Motherland Party (PM Tymoshenko) and the Party of the Regions (PMs Yanukovych and Azarov). Notably, Renewables as Money is not identified in the political discourse by the technocrat government of PM Yehanourov. Similarly, there is no framing of Renewables as Money in PM Yatsenjuk's discourse.

\subsection{Renewables as independence}

Data analysis concurs with previous research which points to the important role of renewables in national energy security (Chum and Overend, 2001), especially in the Eastern European context Jaspal, et al., 2014). Ukraine, as other Eastern European energy importer nations, such as Poland and the Baltics, seeks to minimize its dependence on natural gas imported from the Russian Federation (Tarus and Crandall, 2012). Specifically, PMs Tymoshenko, Yehanurov, Azarov and Yatsenjuk emphasize 
renewables as a variable contributing to Ukraine's political and economic independence. A cross-domain mapping from Renewables onto Independence instantiates the metaphor Renewables as Independence. In a political manifesto by Tymoshenko in 2009, this metaphor is embedded into the context of energy-saving technologies and the use of renewables instead of natural gas:

(5) We made energy saving our strategy, along with the use of renewable energy sources instead of gas, which makes Ukraine more independent from other countries, which makes Ukraine stronger on the energy market.

Renewables as Independence in PM Tymoshenko's discourse shares an identical discursive space with PMs Yehanurov and Azarov, where renewables are regarded in conjunction with energy-saving technologies, gas prices and issues of global climate change. In contrast with the aforementioned contexts of Renewables as Independence, PM Yatsenjuk's framing of Renewables as Independence is associated with renewables as a means of ensuring Ukraine's independence from Russian imported gas:

(6) ...we managed to increase the production of alternative energy by $30 \%$. That is what will provide us with an opportunity to minimize dependence on Russia and to ensure our energy independence.

Renewables as Independence in Yatsenjuk's discourse is evocative of the contention that independence and self-sufficiency are an important variable in the polyphony of media narratives involving renewable and traditional energy sources (Becken, 2014). PM Yatsenjuk's stance on renewables as a means of independence from Russian gas is echoed by other Cabinet members, e.g. Ms Rutycka (2014), deputy minister at the Ministry of European Integration, posits that (7) Today, it is important to calculate how fast we can achieve energy independence... if we direct the money towards building bioenergy plants instead of buying Russian gas.

Whilst the construal of renewables as Independence is consistently present in the political discourse of Ukrainian PMs within the timeframe 2005-2014, Renewables as Independence is concurrent with different foci. For instance, data analysis reveals that PM Tymoshenko regards Renewables as a part of government-endorsed measures to foster an energy-efficient and energy self- sufficient economy which conforms to the environmental targets associated with the Kyoto Protocol, whilst PM Yatsenjuk foregrounds Renewables as an alternative to natural gas which Ukraine imports from Russia. In contrasts with these construals, PM Azarov conceptualizes Renewables as Independence in conjunction with the high price for natural gas imported from Russia, thus highlighting the monetary value of renewables.

\subsection{Renewables as survival}

The role of natural gas in Ukraine's economy is specifically relevant during the heating season, which starts on 15 October every year. Speaking in September 2014, prior to the start of the heating season, PM Yatsenjuk indicates that renewables are important for the country's survival in winter without Russian natural gas:

(8) The Government allocated 500 million UAH to finance municipal programmes of alternative energy sources. Ukraine will be able to survive this winter without Russian gas.

In (8), the cross-domain mapping from Renewables onto Survival instantiates the metaphor Renewables as Survival, which is identified exclusively in Yatsenjuk's discourse compared with the corpus of his predecessors. The presence of the domain Survival and the conceptualization of renewables as a mapping onto Survival are explained by the political reality which Ukraine finds itself in 2014: the war in the East of Ukraine and the annexation of the Crimean peninsula have strained RussianUkrainian bilateral relations. In contrast with previous Russo-Ukrainian gas wars, the present conflict is both a political and a military one. In this political context, a full blockade of Russian natural gas supplies to Ukraine is not precluded. Hence, the role of renewables is elevated to Survival in PM Yatsenjuk's discourse.

Assuming that renewables are framed as a means of survival, which in turn, is potentially associated with adverse conditions, calamities, conflicts and war, it would be logical to expect a mapping onto the domain Weapon, thus resulting in the metaphor Renewables as a Weapon to counterbalance Gas as a Weapon. However, the present data do not contain a direct reference to Gas as a Weapon in political discourse by Tymoshenko, Yehanurov, Yanukovych and Azarov. Additionally, no Ukrainian PM from 2005 to 2014 
conceptualizes renewables as a weapon to counter the view of natural gas as a political tool to exert influence on Ukraine. Thus, the present data are characterized by an absence of the metaphor Renewables as a Weapon. However, in contrast with his predecessors, PM Yatsenjuk explicitly makes use of the ideologically loaded (Romain, 1996, p. 178) metaphor Gas as a Weapon in May 2014 (9) and March 2014 (10):

(9) Ukraine is ready for the market approach. Russia must stop using gas as a new type of weapon.

(10) We must have a closer look at our energy independence, at our energy security. The EU has to speak with one voice on these matters. Russia breaks all contractual obligations by increasing gas prices. By doing so, Russia punishes Ukraine for its European choice. We must give no chances to Russia to use energy sources as a new nuclear weapon.

Following Steen (2008), it can be assumed that Gas as a Weapon in PM Yatsenjuk's discourse is more rhetorical than conceptual in the sense that it is, presumably, a conscious strategy which is identical to the previously reported findings, such as, "Russian natural gas has become an "energy weapon"'” (Högselius, 2013, p. 5). Nevertheless, examples (9) and (10) seem to provide a background for Yatsenjuk's discourse on Renewables, construed as Renewables as Independence and Renewables as Survival. The data indicates that Yatsenjuk refers to Renewables as Survival in the discoursal space of Renewables as Independence and Gas as a Weapon. In this context, the conceptualization of renewables as a means of the country's survival appears to override other metaphors, such as Renewables as Money, Renewables as Ukraine's European Choice and Renewables as a Path to the EU respectively.

\subsection{Renewables as Ukraine's European choice}

The issue of the EU-Ukraine AA dominates the political agendas of PM Yehanourov and PM Azarov, who regard renewables as a token of Ukraine's European choice, as seen in an excerpt from a text by PM Yehanurov in 2005:

(11) ...Ukraine, having declared its political choice to enter the EU, has to produce and use more than 520000 tons of biofuel in 2010.
Political discourse by PM Azarov and his first vice-PM Kluev equates Ukraine's pro-EU political choice with a wider usage of renewables in accordance with EU directives, hence instantiating the metaphor Renewables as Ukraine's European Choice:

(12) Ukraine has made its choice, which path to follow. The President of Ukraine, Viktor Yanoukovych, identified national programmes. One of these programmes envisages the implementation of renewable energy sources and energy effective technologies.

Similarly to PM Yehanurov in (11), Azarov's government construes the issues of renewables in (12) as Ukraine's choice of joining the EU. However, in (12) renewables are regarded both as Ukraine's EU choice and as a path which facilitates Ukraine's future EU entry. Previous research indicates that a prospective candidate country's EU accession is conceptualized as the domain Path (Musolff, 2006), which the aspiring country needs to follow in order to join the EU. In (12), there is a cross-mapping between Path and Renewables, thus instantiating the metaphor Renewables as a Path to the EU. This metaphor is concurrent with Renewables as Ukraine's European Choice, thus reinforcing the role of renewables in Ukraine's EU aspirations.

\section{Conclusions}

The article involves a qualitative study which seeks to identify conceptual metaphors pertaining to renewables in political discourse by Ukrainian PMs Tymoshenko (2005; 2007-2010), Yehanurov (20052006), Yanukovych (2006-2007), Azarov (2010-2014) and Yatsenjuk (2014 - current) respectively. Data analysis indicates that Ukrainian PMs construe renewables in the context of i) securing the country's energy independence and survival; ii) reducing carbon emissions under the aegis of the Kyoto Protocol; iii) attracting investments wielding significant monetary value; and iv) facilitating Ukraine's future EU accession. Data analysis reveals the following conceptual metaphors: Renewables as Money, Renewables as Independence, Renewables as Ukraine's European Choice, Renewables as a Path to the EU and Renewables as Survival. These findings are indicative of the dynamic nature of the conceptualization of renewables in political discourse when any change in the political situation impacts upon the PMs' discoursal space, thus giving rise to novel conceptual 
metaphors, for instance Renewables as Survival. In concert with Fletcher (2009), the present findings suggest that the Ukrainian political discourse involving renewables reflects an ever-changing reality and, consequently, instantiates conceptual metaphors that emerge "from the activity of interconnecting systems of socially situated language use and cognitive activity" (Nerlich, 2010 , p. 421). Specifically, discourse involving renewables may focus upon attracting investments and creating profit, provided that the socio-political context is characterized by the absence of armed conflict. However, with the war in the East of Ukraine in 2014, renewables are construed by PM Yatsenjuk as a means of ensuring Ukraine's energy security and are not framed as a variable in combatting global climate change. The framing of renewables as Survival in Yatsenjuk's discoursal space is concurrent with the conceptual metaphor Gas as a Weapon, which is explicitly present in the Ukrainian political discourse in 2014 but absent in contexts prior to 2014. Concurring with Kelsey and Bennett (2014, p.40), the present findings support a contention that political discourse is dynamically constructed and reconstructed by different participants in discursive events, thus instantiating a variety of conceptual metaphors.

These data indicate that Renewables as Independence has been construed as a recurring part of Ukrainian political discoursal space from 2005 onwards. Renewables as Independence appears to be concurrent with Gas as a Weapon, which is explicitly framed by PM Yatsenjuk in 2014. It has been found in the present study that Gas as a Weapon does not facilitate the construal of renewables regarded by Ukrainian PMs as a weapon to counterbalance the import of Russian natural gas. Hence, the metaphor Renewables as a Weapon has not been identified in the analysed corpus. Data analysis seems to indicate that whilst Gas maps onto the domain Weapon, Renewables are not construed as mappings onto Weapon. Consequently, it can be assumed that Renewables are associated with neutral and positive connotations, such as Independence, Survival, European Choice, a $P a t h$ and Money respectively.

\section{Acknowledgments}

The present article is written with financial support from the LINGCLIM project financed by the Norwegian Research Council and University of Bergen, Norway.

\section{References}

ANDERSON, R. D. Jr., 2001. Metaphors of dictatorship and democracy: Change in the Russian political lexicon and the transformation of Russian politics. Slavic Review, vol. 60, no. 2, pp. 312-335.

AZAROV, M., 2010. Ukraine-Finland: European rapprochement. Baltic Rim Economies, no. 5, pp. 173.

BECKEN, S., 2014. Oil depletion or a market problem? A framing analysis of peak oil in The Economist news magazine. Energy Research \& Social Science, no. 2, pp. 125-134.

BILGIN, M., 2011. Energy security and Russia's gas strategy: The symbiotic relationship between the state and firms. Communist and Post-Communist Studies, no. 44, pp. 119-127.

BLANK, S., 2008. Russia and the Black Sea's frozen conflicts in strategic perspective. Mediterranean Quarterly, vol. 19, no. 3, pp. 23-54.

BLOCKMANS, S. and VAN VOOREN, B., 2012. Revitalizing the European 'Neighbourhood Economic Community': The Case for Legally Binding Sectoral Multilateralism. Working papers of Leuven Centre for Global Governance Studies, no. 91, pp.1-34.

BOUDET, $\mathrm{H}$. et al., 2014. "Fracking" controversy and communication: Using national survey data to understand public perceptions of hydraulic fracturing. Energy Policy, no. 65, pp.5767.

CAMERON, F., 2010. The politics of EU-Russia energy relations. EU-Russia Energy Relations. OGEL collection, Euroconfidential, pp. 25-38.

CAMERON, L., et al., 2009. The discourse dynamics approach to metaphor and metaphor-led discourse analysis. Metaphor and Symbol, vol. 24 no. 2, pp.63-89.

CARVALHO, A., 2010. Media(ted) discourses and climate change: a focus on political subjectivity and (dis)engagement. WIREs Climate Change, no. 1, pp.172-179.

CHERP, A. and JEWELL, J., 2011. The three perspectives on energy security: intellectual history, disciplinary roots and the potential for integration. Current Opinion in Environmental Sustainability, vol. 3, no. 4, pp. 202-212. 
CHILTON, P., 2004. Analysing political discourse: Theory and practice. Routledge.

CHUM, H. L. and OVEREND, R., 2001. Biomass and renewable fuels. Fuel Processing Technology, vol.71, no. 1, pp. 187-195.

CROFT, W. and CRUSE, D. A., 2004. Cognitive linguistics. Cambridge University Press.

DE CILLIA, R., et al., 1999. The discursive construction of national identities. Discourse \& Society, vol. 10, no. 2, pp.149-173.

FLETCHER, A. L., 2009. Clearing the air: the contribution of frame analysis to understanding climate policy in the United States. Environmental Politics, vol.18, no. 5, pp. 800-816.

FLØTTUM K., et al., 2014. Representations of the future in English language blogs on climate change. Global Environmental Change, no. 29, pp. 213-222.

GIBBS, R. W. Jr., 2011 . Evaluating conceptual metaphor theory. Discourse Processes, vol. 48, no. 8, pp. 529-562.

GLYNOS, J., et al., 2009. Discourse analysis: Varieties and methods.[online] [Accessed 15 January 2015]. Available at http://eprints.ncrm.ac.uk/796/

GOLDMAN, A. Y. , 2010. Geopolitical Struggles: The Case of Russo-Ukrainian Natural Gas Tensions. [online] [Accessed 15 January 2015]. Available at http://arizona.openrepository.com/arizona/handle/10150/146044

HART, C., 2008. Critical discourse analysis and metaphor: toward a theoretical framework. Critical Discourse Studies, vol. 5, no. 2, pp. 91-106.

HART, C., 2011 . Force-interactive patterns in immigration discourse: A Cognitive Linguistic approach to CDA. Discourse \& Society, vol. 22, no. 3, pp. 269-286.

HART, C., 2014. Constructing contexts through grammar: Cognitive models and conceptualization in British newspaper reports of political protests. Discourse in Context: Contemporary Applied Linguistics, no. 3.

HÖGSELIUS, P., 2013. Red Gas. NY: Palgrave Macmillan.

IJZERMAN, H. and KOOLE, S., 2011. From perceptual rags to metaphoric riches-Bodily, social, and cultural constraints on sociocognitive metaphors: Comment on Landau, Meier, and Keefer (2010). Psychological Bulletin, vol. 137, no. 2, pp. 355-361.

JASPAL, R., et al., 2014. Fracking in the Polish press: Geopolitics and national identity. Energy Policy, no 74, pp. 253-261.

KATZ, M. N., 2005. Exploiting rivalries for prestige and profit: An assessment of Putin's foreign policy approach. Problems of Post-Communism, vol. 52, no. 3, pp. 25-36.

KELSEY, D. and BENNETT, L., 2014. Discipline and resistance on social media: Discourse, power and context in the Paul Chambers 'Twitter Joke Trial'. Discourse, Context and Media, no.3, pp. 37-45.

KORPPOO, A. and GASSAN-ZADE, O., 2014. Lessons from JI and GIS for post-2012 carbon finance mechanisms in Russia and Ukraine. Climate Policy, vol. 14, no. 2, pp. 224-241.

KRZYZANOWSKI, M. and WODAK, R., 2011. Political strategies and language policies: the European Union Lisbon strategy and its implications for the EU's language and multilingualism policy. Language Policy, vol. 10, no. 2, pp. 115-136.

KRATOCHVIL, P., et al., 2011. The EU as a 'Framing Actor': Reflections on media debates about EU foreign policy. JCMS: Journal of Common Market Studies, vol. 49, no. 2, pp.391412.

LAKOFF, G. and JOHNSON, M., 1980. Metaphors we live by. Chicago: University of Chicago Press.

LANCOR, R., 2014. Using metaphor theory to examine conceptions of energy in biology, chemistry, and physics. Science \& Education, vol. 23, no. 6, pp. 1245-1267.

LANGACKER, R. W., 1991. Foundations of cognitive grammar, vol. 2. Descriptive application. LILLIESTAM, J. and ELLENBECK, S., 2011. Energy security and renewable electricity trade Will Desertec make Europe vulnerable to the "energy weapon"?. Energy Policy, vol. 39, no. 6, pp.3380-3391.

MALEK, M., 2012. Challenges of European Union's Energy Policy in the Central Asia and Caspian Region. Elektronik Siyaset Bilimi Araştırmaları Dergisi, no. 5, pp.1-20.

MCGLONE, M. S., 2007. What is the explanatory value of a conceptual metaphor? Language \& Communication, vol. 27, no. 2, pp. 109-126.

MUSOLFF, A., 2004. Metaphor and political discourse. New York: Palgrave Macmillan.

MUSOLFF, A., 2006. Metaphor Scenarios in Public Discourse. Metaphor and Symbol, vol. 21 , no. 1, pp. 23-38. 
NERLICH,B., 2010. 'Climategate': paradoxical metaphors and political paralysis. Environmental Values, vol. 19, no. 4, pp. 419-442.

NICHOL, J. et al., 2006. Russia's cutoff of natural gas to Ukraine: Context and implications. Congressional Research Service, Library of Congress.

NYGREN, B., 2008. Putin's use of natural gas to reintegrate the CIS region. Problems of PostCommunism, vol. 55, no. 4, pp. 3-15.

OBYDENKOVA, A. and LIBMAN, A., 2014. Understanding the foreign policy of autocratic actors: ideology or pragmatism? Russia and the Tymoshenko trial as a case study. Contemporary Politics, vol. 20, no. 3, pp. 347-364.

PAASI, A., 2001. Europe as a social process and discourse considerations of place, boundaries and identity. European urban and regional studies, vol. 8, no. 1, pp. 7-28.

PIDGEON, N., 2012. Public understanding of, and attitudes to, climate change: UK and international perspectives and policy. Climate Policy, vol. 12, no. 1, pp. 85-106.

PIDGEON, N.F., KASPERSON, R.K. and SLOVIC, P., 2003. The social amplification of risk. Cambridge: Cambridge University Press.

PRINCEN, T., 2010. Speaking of sustainability: the potential of metaphor. Sustainability: Science, Practice, \& Policy, vol. 6, no. 2, pp. 60-65.

RALBOVSKY, J., 2011. Renewable energy policy in Ukraine. Unpublished Bachelor's thesis. [online] [Accessed 15 January 2015]. Available at http://surface.syr.edu/honors_capstone/299/

ROGERS-HAYDEN, T., et al., 2011. 'Energy security' and 'climate change': Constructing UK energy discursive realities. Global Environmental Change, no. 21, pp. 134-142.

ROMAINE, S., 1996. War and peace in the global greenhouse: metaphors we die by. Metaphor and Symbol, vol. 11, no. 3, pp. 175-194.

RUTLAND, P., 2008. Russia as an energy superpower. New Political Economy, vol. 13, no. 2, pp. 203-210.

SHAW, C. and NERLICH, B., 2015. Metaphor as a mechanism of global climate change governance: A study of international policies, 1992-2012. Ecological Economics, no. 109, pp. 34-40.

SHKARLET, S. and PETRAKOV, I., 2013. Environmental taxation evolution in Ukraine: Trends, Challenges and Outlook. The Herald of Chernihiv State Technological University, vol. 4, no. 64, pp. 287-301.

SMITH, K. C., 2007. Russian energy pressure fails to unite Europe. CSIS Euro-Focus, vol. 13, no. 1 , pp. 1-8.

SMITH STEGEN, K., 2011. Deconstructing the "energy weapon": Russia's threat to Europe as case study. Energy Policy, vol. 39, no. 10, pp. 6505-6513.

STEEN, G., 2008. The paradox of metaphor: Why we need a three-dimensional model of metaphor. Metaphor and Symbol, vol. 23, no. 4, pp. 213-241.

TARUS, T. and CRANDALL, M., 2012. Is Russia a threat to Estonian energy security? Baltic Journal of Political Science, no. 1, 77-91.

TROMBETTA, M. J., 2008. Environmental security and climate change: analysing the discourse. Cambridge Review of International Affairs, vol. 21, no. 4, pp. 585-602.

VAN DIJK, T. A., 2002. Political discourse and political cognition. Politics as text and talk: Analytical approaches to political discourse, no.204, pp. 236.

WALKER, M., 2007. Russia v. Europe: The energy wars. World Policy Journal, pp. 1-8.

WIGEN, E., 2012. Pipe Dreams or Dream Pipe?: Turkey's Hopes of Becoming an Energy Hub. The Middle East Journal, vol. 66, no. 4, pp. 598-612.

WILSON, K. M., 2000. Communicating climate change through the media. Environmental risks and the media, pp. 201-217.

WODAK, R., 2011 . The discourse of politics in action: Politics as usual. Basingstoke: Palgrave Macmillan.

ZHERYBOR, D., 2010. Gas price increase for population and factual gas price dividends for traditional industries: What is the future of Ukrainian economy? КИї̈СьКИЙ ІНСТИТУТ БІЗНЕСУ ТА ТЕХНОЛОГІЙ, vol. 3, nо. 13, pp. 6-9.

www.kmu.gov.ua

www.tymoshenko.ua

www.ukurier.gov.ua

www.ukrinform.ua

zakon4.rada.gov.ua 
Author's address and contact details

Dr Oleksandr Kapranov

Department of Foreign Languages

University of Bergen

Postboks 7805

5020 Bergen

Norway

E-mail: Oleksandr.Kapranov@uib.no 